포식성 이리응애 4종의 담배가루이 알 포식능력 비교 평가

김황용* · 이용휘 · 김정환 · 김용헌

농촌진흥청 국립농업과학원 곤충산업과

\title{
Comparison on the Capability of Four Predatory Mites to Prey on the Eggs of Bemisia tabaci (Hemiptera: Aleyrodidae)
}

Hwang-Yong Kim*, Yong-Hwi Lee, Jeong-Hwan Kim and Yong-Heon Kim

Applied Entomoloy Division, National Academy of Agricultural Science, Rural Development Administration, Suwon 441-707, Korea

\begin{abstract}
On the leaf disc of fruit vegetables (cucumber, sweet pepper, tomato, egg plant, oriental melon), it has been evaluated that the capability of four predatory mites (Amblyseius swirskii Athias-Henriot, Neoseiulus barkeri (Hughes), N. cucumeris (Oudemans), N. californicus (McGregor)) to prey on the eggs of Bemisia tabaci (Gennadius) and to lay own eggs. The most aggressive mite was A. swirskii which had consumed about 9 12 eggs in a day. The quantity of eggs consumed by $N$. barkeri, N. cucumeris and $N$. californicus was about $6 \sim 9,4 \sim 6$ and $1 \sim 4$, respectively. The most productive mite was also $A$. swirskii which had laid about 1.2 1.9 eggs in a day. The others could not lay more than 0.5 eggs in a day.
\end{abstract}

KEY WORDS : Bemisia tabaci, Amblyseius swirskii, Neoseiulus barkeri, Neoseiulus cucumeris, Neoseiulus californicus

초 록 : 시설과채류(오이, 착색단고추, 토마토, 가지, 참외)의 잎 절편에서 지중해이리응애, 나팔이리응애, 오이이리응애, 사막이리응애를 대상으로 담배가루이 알에 대한 포식능력과 산란능력을 비교 평가하였다. 지중해이리응애의 일평균 담배가루이 알 포식량이 9 12개로 가장 많았으며, 나팔이리응애, 오이이리응애, 사막이리응애가 각각 6 9개, 4 6개, 1 4개로 뒤를 이었다. 일평균 산란수도 지중해이리응애가 1.2 1.9개로 가장 많았으며, 다른 포식응애들은 0.5 개를 넘지 않았다.

검색어 : 담배가루이, 지중해이리응애, 나팔이리응애, 오이이리응애, 사막이리응애

최근 담배가루이 Q계통이 국내에 유입되어 시설과채류 를 중심으로 큰 피해를 주고 있다(Lee et al., 2005). 담배 가루이가 배설한 감로는 그 자체가 끈적거릴 뿐만 아니라 그을음병을 유발하기 때문에, 담배가루이가 발생하면 과 실의 상품성이 현저하게 떨어진다(Byrne, 1999). 그리고 담배가루이 밀도가 높아지면, 작물체가 고사하거나 생육
이 부진하게 되어 작기 단축이 불가피하며, 토마토 등 일부 작물에서 착색불량과의 비율이 높아진다. 특히 담배 가루이는 토마토황화잎말림바이러스(TYLCV: Tomato Yellow Leaf Curl Virus)를 비롯한 100종 이상의 바이러 스를 매개할 수 있는 것으로 알려져 있으므로 각별한 주의 가 필요하다(Jones, 2003).

*Corresponding author. E-mail: kim3@rda.go.kr 
농약을 살포하는 것이 담배가루이를 방제하는 일반적 인 방법인데, 담배가루이 Q계통의 경우 농약에 대한 저항 성을 획득할 가능성이 매우 높다는데 문제가 있다. 담배가 루이 $\mathrm{Q}$ 계통은 특히 네오니코티노이드계 농약에 대한 저 항성이 쉽게 발달하는 것으로 알려져 있으며(Nombela et al., 2001), IGR계통인 피리프록시펜에 대해서도 저항 성을 획득한 사례가 보고되어 있다(Horowitz et al., 2003). 유사한 성분의 약제를 연용하지 않으면 약제 저항성 출현 을 지연시킬 수 있지만, 좀 더 근본적인 대책마련을 위해 서는 생물적 방제 중심의 종합방제체계를 구축할 필요가 있다.

이와 같은 상황에서 이리응애과(Acari: Phytoseiidae)에 속하는 포식성 응애류가 담배가루이 방제용 천적으로 주 목을 받고 있다. 특히 지중해이리응애 (Amblyseius swirskii Athias-Henriot)는 이미 오이에서 담배가루이의 밀도를 억제할 수 있는 것으로 알려져 있으며(Nomikou et al., 2002), 최근에는 남부 스페인에서 착색단고추를 비롯한 시설원예작물에 발생하는 담배가루이를 대상으로 활용되 고 있다(Calvo et al., 2006). 지중해이리응애는 지중해 지역이 원산인 포식성 응애로서, 2006년부터 수입이 허용 이 되어 국내 천적회사들을 통해 영농현장에 보급되고 있는데, 특히 착색단고추 재배 농업인들로부터 호평을 받고 있으며, 향후 다른 작물로 적용 범위가 점차 확대될 것으로 기대된다. 다만 지중해이리응애와 비슷한 생태적 지위를 가지고 있는 다른 포식성 응애류를 활용하는 방안 을 충분히 검토하지 못하였기 때문에, 우리 농업 현실에서 지중해이리응애의 활용이 최선의 선택이었는지에 대한 판단근거가 아직까지 충분하지 않은 실정이다. 따라서 현재 국내에서 상품화되어 있거나 상업적 대량 생산이 가능 한 이리응애과 포식응애류 3종(나팔이리응애(Neoseiulus barkeri (Hughes)), 오이이리응애(N. cucumeris (Oudemans)), 사막이리응애(N. californicus (McGregor)))을 선택하여 각 종의 담배가루이 포식능력을 지중해이리응애와 비교 평가해 보았다.

\section{재료 및 방법}

\section{대상 작물}

국내에서 재배되는 시설과채류 중에서 담배가루이로 인한 피해가 심하거나 향후 담배가루이로 인한 피해 발생 이 우려되는 작물 중에서, 토마토, 착색단고추, 오이, 참외,
가지를 실험 대상 작물로 선정하였다. 작물 별로 실험에 이용한 품종은 각각 서광(토마토), 스페셜(착색단고추), 백봉다다기(오이), 금달다(참외), 흑마장(가지)이었다. 각 작물은 내경 $15 \mathrm{~cm}$ 의 화분을 이용하여 국립농업과학원 내 유리 온실에서 20 30 cm 정도의 크기로 키운 다음 실험에 이용하였다.

\section{담배가루이 사육}

2005년 경남 진주지역의 착색단고추 재배 지역에서 채 집된 담배가루이를 계대 사육하여 실험에 이용하였다. 주로 착색단고추를 이용하여 담배가루이 개체군을 유지 하였으며, 여건에 따라 일시적으로 토마토, 참외, 오이 등을 먹이 식물로 이용하였다.

\section{대상 천적}

지중해이리응애, 나팔이리응애, 오이이리응애, 사막이 리응애를 실험 대상 천적으로 이용하였다. 나팔이리응애 는 2000년 전남 구례지역에서 채집하여 긴털가루응애를 이용하여 $25^{\circ} \mathrm{C}$ 에서 계대 사육 중인 것을 이용하였으며, 나팔이리응애를 제외한 나머지 응애는 (주)세실에서 구입 한 이후 $25^{\circ} \mathrm{C}$ 에서 6 개월 이상 계대 사육한 다음 실험에 이용하였다. 지중해이리응애와 오이이리응애는 나팔이 리응애와 동일한 조건에서 사육하였으며, 사막이리응애 는 강낭콩에 접종한 점박이응애를 먹이로 사육하였다.

\section{실험 방법}

아크릴로 만든 직육면체 모양의 상자 $(25 \mathrm{~W} \times 25 \mathrm{D} \times$ $40 \mathrm{H} \mathrm{cm}$ )에 작물을 넣은 다음, $1,000 \sim 2,000$ 마리의 담배가 루이를 접종하여 16 시간 동안 산란 받아 먹이로 이용하였 다. 그런 다음 직경 $3 \mathrm{~cm}$ 의 둥근 절편을 만들고 담배가루 이 알을 25 개만 남기고 나머지는 제거하였다. 잎 절편을 싱싱하게 유지하기 위하여, 덮개에 직경 $15 \mathrm{~mm}$ 의 망사 구멍이 있는 납작한 원반 모양의 사육용기(Ø $50 \mathrm{~mm} \times$ $15 \mathrm{H} \mathrm{mm}$ )에 $1 \%$ 한천수용액을 $5 \mathrm{~mm}$ 두께로 굳힌 다음 잎 윗면을 한천에 부착시켰다. 그런 다음 움직임이 활발한 포식성 응애 암컷을 한 마리씩 접종하고, 사육용기를 뒤집 어서 $25^{\circ} \mathrm{C}$, 장일조건( $\left.16 \mathrm{~L}: 8 \mathrm{D}\right)$ 에 두었다. 그리고 매일 신 선한 담배가루이 알을 동일한 방법으로 공급하면서, 24시 간 간격으로 4 일간 각 개체 별 담배가루이 포식량과 산란 수를 집계하였다. 각 조건 별로 최소한 30 개체 이상을 
실험에 이용하였다.

\section{분석 방법}

처음 하루 동안의 포식량과 산란수는 실험 이전의 사육 조건에 따른 영향을 많이 받았을 것으로 판단하여, 2일차 부터 4 일차까지 사흘 동안 수집한 자료를 분석에 이용하 였다. 실험 기간 동안 생존하지 못한 경우, 개체별 생존 여부만 파악하고 이후 분석 대상에서 제외하였다. 각 포식 응애의 일평균 담배가루이 알 포식량과 담배가루이 알을 먹이로 하였을 때의 일평균 산란수를 구하였으며, 포식응 애의 종류에 따른 산란수가 차이가 있는지 살펴보기 위하 여 분산분석법(ANOVA)으로 각 작물별 자료를 통계적으 로 분석하였다. 통계처리에는 SAS Enterprise Guide 4 를 이용하였다. 평균 간 차이를 비교하기 위해서는 최소유의 차(LSD)검정을 이용하였다. 한편 지중해이리응애에 대 해서는, 처음 하루 동안의 산란수와 나머지 사흘 동안의 일평균 산란수를 쌍체비교(paired t-test)하는 방법을 통하 여, 긴털가루응애가 대량증식용 먹이로 적합한지 간접적 으로 평가해 보았다.

\section{결과 및 고찰}

다른 포식성 응애류에 비해, 지중해이리응애가 담배가 루이의 천적으로서 유망한 생물적 특성을 두루 갖추고
있는 것으로 판단된다. 지중해이리응애는 생존율, 포식량, 산란수 등 모든 기준에서 뛰어난 특성을 보였으며, 자세한 내용을 살펴보면 다음과 같다.

먼저 응애 종류에 따라서 주어진 실험 조건에서 생존하 는 능력의 차이가 있었다(Table 1). 작물에 따라서 다소 차이가 있기는 하지만, 지중해이리응애는 $88 ~ 100 \%$ 의 개 체가 생존하였고, 사막이리응애의 생존율도 $74 \sim 88 \%$ 로 비교적 높았지만, 오이이리응애와 나팔이리응애의 생존 율은 각각 55 83\%와 21 67\% 정도에 지나지 않아 상대적 으로 생존 능력이 떨어지는 것으로 나타났다. 지중해이리 응애는 대체로 잎 절편 내부에 정착하여 느린 움직임을 보이는 반면, 다른 포식 응애들은 사육 용기 곳곳을 빠르 게 배회하는 등 실험 환경에 적응하지 못하는 행동을 보였 는데, 아마도 담배가루이 알이 다른 포식응애의 먹이로 적합하지 않았기 때문으로 판단된다.

모든 작물에 대하여 포식응애의 종류에 따라 담배가루 이 알 포식량이 달라지는 것으로 분석되었다 $(\mathrm{p}<0.001)$. 작물의 종류에 따라 다소 차이는 있었지만, 지중해이리응 애의 일평균 포식량이 9 12개 정도로 월등히 많았으며, 나팔이리응애(6 9개), 오이이리응애(4 7개), 사막이리응 애(1 4개)가 차례로 뒤를 이었다(Table 2). 예외적으로 파프리카에서는 지중해이리응애와 나팔이리응애의 포식 량 차이가 뚜렷하지 않았고, 참외에서는 오히려 오이이리 응애의 포식량이 나팔이리응애의 포식량에 비해 조금 많 았지만 통계적인 유의성은 없었다. 작물별 생존율을 함께 고려하면, 나팔이리응애와 오이이리응애의 담배가루이

Table 1. Survival rate of predatory mites on leaf disc during the pre-experimental period of one day and experimental period of three days

\begin{tabular}{lccccc}
\hline \multirow{2}{*}{ Predatory Mite } & \multicolumn{5}{c}{ Survival rate on leaf disc $(N=$ replication) } \\
\cline { 2 - 6 } & Cucumber & Sweet Pepper & Tomato & Egg Plant & Oriental Melon \\
\hline Amblyseius swirskii & $0.970(33)$ & $0.882(34)$ & $1.000(30)$ & $0.800(30)$ & $0.967(30)$ \\
Neoseiulus barkeri & $0.213(47)$ & $0.667(33)$ & $0.567(30)$ & $0.567(30)$ & $0.433(30)$ \\
N. cucumeris & $0.548(31)$ & $0.697(33)$ & $0.647(34)$ & $0.833(30)$ & $0.767(30)$ \\
N. californicus & $0.882(34)$ & $0.767(30)$ & $0.833(30)$ & $0.867(30)$ & $0.743(35)$ \\
\hline
\end{tabular}

Table 2. Daily number of Bemisia tabaci eggs consumed by each predatory mite on leaf disc

\begin{tabular}{lccccc}
\hline \multirow{2}{*}{ Predatory Mite } & \multicolumn{3}{c}{ Number of Eggs consumed by a predatory mite on leaf disc (mean \pm s.e.) } \\
\cline { 2 - 6 } & Cucumber & Sweet Pepper & Tomato & Egg Plant & Oriental Melon \\
\hline Amblyseius swirskii & $8.57 \pm 0.49^{\mathrm{A}}$ & $11.00 \pm 0.42^{\mathrm{A}}$ & $11.79 \pm 0.38^{\mathrm{A}}$ & $12.17 \pm 0.45^{\mathrm{A}}$ & $11.55 \pm 0.58^{\mathrm{A}}$ \\
Neoseiulus barkeri & $8.47 \pm 1.15^{\mathrm{A}}$ & $8.61 \pm 0.42^{\mathrm{B}}$ & $6.35 \pm 0.36^{\mathrm{B}}$ & $8.55 \pm 0.70^{\mathrm{B}}$ & $6.74 \pm 0.58^{\mathrm{B}}$ \\
N. cucumeris & $4.31 \pm 0.24^{\mathrm{B}}$ & $6.58 \pm 0.30^{\mathrm{C}}$ & $4.14 \pm 0.40^{\mathrm{C}}$ & $4.48 \pm 0.31^{\mathrm{C}}$ & $7.10 \pm 0.51^{\mathrm{B}}$ \\
N. californicus & $1.04 \pm 0.24^{\mathrm{C}}$ & $4.17 \pm 0.53^{\mathrm{D}}$ & $1.71 \pm 0.34^{\mathrm{D}}$ & $3.15 \pm 0.48^{\mathrm{D}}$ & $1.91 \pm 0.33^{\mathrm{C}}$ \\
\hline
\end{tabular}

Note: Within a column, means with same letter are not significantly different $(\mathrm{P}>0.05$, LSD) 
포식능력 차이는 크지 않은 것으로 판단된다. 생존율이 비교적 높았던 사막이리응애의 경우에는 오히려 담배가 루이 알 포식량이 매우 적은 것으로 나타났다.

일평균 산란수 또한 모든 작물에서 포식응애의 종류에 따라 달라지는 것으로 분석되었는데 $(\mathrm{p}<0.001)$, 지중해이 리응애의 산란수가 월등히 많았다. 다른 포식응애들은 어떤 작물에서도 일평균 산란수가 0.5 개를 넘지 못하였지 만, 지중해이리응애의 일평균 산란수는 작물별로 1.2 1.9 개 내외로 비교적 많았다(Table 3). 지중해이리응애 전체 의 총포식량을 총산란수로 나누는 방법으로 전환율을 계 산한 결과, 착색단고추 5.9 , 토마토 7.1 , 오이 7.1 , 참외 8.2 , 가지 9.6으로 나타났다. 즉, 이와 같은 결과는 지중해 이리응애가 알 한 개를 낳기 위해서 담배가루이 알을 $6 \sim 10$ 개씩 포식하는 것으로 볼 수 있다.

이와 같은 결과는 담배가루이 알과 약충을 먹이로 충분 하게 공급하였을 때 지중해이리응애와 나팔이리응애 모 두 일평균 산란수가 1.5 개 내외로 큰 차이를 보이지 않는 다는 Nomikou 등(2001)의 연구 결과와 대조를 이루는데, Nomikou 등의 실험에서 나팔이리응애의 산란 활동이 활 발했던 것은 감로 등 다른 영양물질의 섭취가 가능했기 때문으로 추측된다. 꽃가루나 감로 등의 보조적인 먹이를 섭취하는 현상은 포식성 이리응애에게서 흔하게 관찰될 뿐만 아니라, 일부 포식성 천적들은 이들을 섭취해야 정상 적으로 산란이 가능한 것으로 알려져 있다 (McMurtry and Croft, 1997). Swirski 등(1970)은 사막이리응애의 일 평균 산란수를 0.13 내외로 보고한 바 있는데, 이번 실험 결과는 0.3 0.4개로 약간 많게 조사되었다. 한편 점박이 응애를 사막이리응애의 먹이로 하였을 경우에는 $25^{\circ} \mathrm{C}$ 에
서 일평균 산란수가 1.94 개 정도인 것으로 보고된 바 있다 (Canlas et al., 2006).

지중해이리응애는 모든 작물에서 처음 하루 동안의 적 응기간보다 나머지 사흘 동안의 실험기간에 일평균 산란 수가 통계적으로 고도로 유의하게 많았다(Table 4). 즉 전날 긴털이리응애를 섭취하였을 때 보다 담배가루이 알 을 섭취하였을 때 좀 더 산란수가 많았던 것이다. 반면, 오이이리응애와 사막이리응애는 실험기간과 적응기간의 산란수 차이가 전혀 없어서 대조를 이루고 있다. 이와 같은 결과는 긴털가루응애가 지중해이리응애의 대량 증 식용 먹이로 적합하지 않다는 천적 생산 업계의 일반적인 진술과 부합하는 측면이 있다. 일반적으로 지중해이리응 애의 상업적 생산에는 설탕응애가 적합한 것으로 알려져 있지만, 설탕응애를 이용하여 지중해이리응애를 생산할 경우 관련 사항에 대한 국제 특허를 소지한 네덜란드의 코퍼트(Koppert)사와 특허 분쟁이 발생할 우려가 있으므 로, 국내 천적회사의 주의와 함께 대체 먹이를 탐색할 필요가 있다.

지중해이리응애는 담배가루이 알 포식량이 많은 것 이 외에도 다양한 장점을 갖추고 있어서 앞으로 활용도가 높을 것으로 기대된다. 꽃가루를 비롯한 식물 성분만으로 증식이 가능하기 때문에 해충 발생 이전에 포장에 정착시 킬 수 있으며, 필요에 따라 꽃가루를 함께 처리해 주면 오이에서 담배가루이 밀도억제 효과가 높아지는 것으로 알려져 있다(Nomikou et al., 2003). 담배가루이 뿐만 아 니라 총채벌레에 대한 포식 능력 또한 뛰어나서 다목적 활용이 가능하며(Messelink et al., 2006), 담배가루이 알 을 주로 포식하기 때문에 약충을 공격하는 기생성 천적들

Table 3. Daily number of eggs laid by each predatory mite on leaf disc

\begin{tabular}{lccccc}
\hline \multirow{2}{*}{ Predatory Mite } & \multicolumn{4}{c}{ Number of Eggs laid by a predatory mite on leaf disc (mean \pm s.e.) } \\
\cline { 2 - 6 } & Cucumber & Sweet Pepper & Tomato & Egg Plant & Oriental Melon \\
\hline Amblyseius swirskii & $1.21 \pm 0.10^{\mathrm{A}}$ & $1.86 \pm 0.11^{\mathrm{A}}$ & $1.67 \pm 0.11^{\mathrm{A}}$ & $1.26 \pm 0.13^{\mathrm{A}}$ & $1.41 \pm 0.12^{\mathrm{A}}$ \\
Neoseiulus barkeri & $0.47 \pm 0.14^{\mathrm{B}}$ & $0.21 \pm 0.05^{\mathrm{C}}$ & $0.19 \pm 0.05^{\mathrm{B}}$ & $0.51 \pm 0.13^{\mathrm{B}}$ & $0.03 \pm 0.03^{\mathrm{C}}$ \\
N. cucumeris & $0.06 \pm 0.03^{\mathrm{C}}$ & $0.49 \pm 0.06^{\mathrm{B}}$ & $0.17 \pm 0.07^{\mathrm{B}}$ & $0.33 \pm 0.11^{\mathrm{B}}$ & $0.29 \pm 0.10^{\mathrm{BC}}$ \\
$N$. californicus & $0.32 \pm 0.08^{\mathrm{BC}}$ & $0.27 \pm 0.07^{\mathrm{BC}}$ & $0.24 \pm 0.07^{\mathrm{B}}$ & $0.41 \pm 0.11^{\mathrm{B}}$ & $0.42 \pm 0.08^{\mathrm{B}}$ \\
\hline
\end{tabular}

Note: Within a column, means with same letter are not significantly different $(\mathrm{P}>0.05, \mathrm{LSD})$

Table 4. Paired t-test results about the difference on the number of eggs laid by Amblyseius swirskii per day, between experimental period and pre-experimental period

\begin{tabular}{cccccc}
\hline \multirow{2}{*}{ Predatory Mite } & \multicolumn{5}{c}{ Difference on the number of eggs (mean \pm s.e.) } \\
\cline { 2 - 6 } & Cucumber & Sweet Pepper & Tomato & Egg Plant & Oriental Melon \\
\hline A. swirskii & $0.58 \pm 0.15^{* *}$ & $1.17 \pm 0.17^{* *}$ & $1.50 \pm 0.12^{* *}$ & $0.60 \pm 0.17^{* *}$ & $0.96 \pm 0.13^{* *}$ \\
\hline
\end{tabular}

Note: $* *$ means the difference highly significant statistically 
과의 상호보완적 활용가치가 매우 뛰어나다. 또한 엽육 조직을 섭취하지 않기 때문에(Nomikou et al., 2003), 관 주 처리를 이용한 화학적 방제를 지중해이리응애 투입과 병행할 수 있는 여지가 있다.

지금까지 살펴본 바와 같이 지중해이리응애의 잠재적 인 능력은 뛰어나지만, 실제 작물에 적용하기 위해서는 다각적인 검토가 필요하다. 예를 들어 토마토에서는 지중 해이리응애의 분산 능력이 매우 떨어지기 때문에, 실질적 인 활용이 곤란한 상황이다. 토마토 줄기에 분배기를 걸어 두면 바깥으로 나오지 않고, 붓을 이용하여 토마토 잎에 지중해이리응애를 접종하면 한 곳에 뭉쳐서 이동을 하지 않는 현상을 관찰할 수 있는데, 토마토가 분비하는 화학물 질이 지중해이리응애의 행동에 특정 영향을 끼칠 가능성 이 높다. 지중해이리응애를 처음으로 상품화 시킨 네덜란 드의 코퍼트사는 자사의 홈페이지를 통해 지중해이리응 애가 며칠 정도의 짧은 기간 동안은 토마토에 정착할 수 있다고 밝히고 있는데, 이번 연구 결과에서도 토마토 잎 절편에서는 지중해이리응애가 정상적으로 담배가루이 알 을 포식하였으며, 산란도 정상적으로 이루어졌다. 토마토 에서 지중해이리응애를 활용하는 방안에 대해서는 앞으 로도 많은 연구가 필요할 것으로 판단된다. 참외에 대해서 도 지중해이리응애의 효과에 대해서 충분한 검토가 필요 하다. 참외 재배는 다른 작물에 비해서 고온 조건에서 이루어지고, 작물이 직립하는 것이 아니라 지표면을 덮는 특징이 있기 때문에, 일반적인 시설 과채류에서와는 다른 행동을 보일 가능성을 배제할 수 없다. 결론적으로 지중해 이리응애를 활용하여 담배가루이 방제체계를 구성하는 것이 바람직하지만, 각 작물별로 최적의 방제 모형을 구축 하기 위해서는 지속적인 연구가 필요하다.

\section{사 사}

본 논문은 2007년부터 2008년 사이에 농촌진흥청 연구 과제(천적을 이용한 담배가루이 방제기술 개발)를 수행하 는 과정에서 얻은 결과를 바탕으로 작성되었습니다. 연구 대상이 되는 천적을 사육관리하고 원활한 연구 수행이 이루어지도록 도와 주신 농촌진흥청 국립농업과학원 곤 충산업과 김정란, 이미숙, 최은희 선생님께 깊은 감사를 드립니다.

\section{Literature Cited}

Byrne, D.N. 1999. Migration and dispersal by the sweet potato whitefly, Bemisia tabaci. Agri. Forest Meteorol. 97: 309-316.

Calvo, J., P. Fernández, K. Bolckmans and J.E. Belda. 2006. Amblyseius swirskii (Acari: Phytoseiidae) as a biological control agent of the tobacco whitefly Bemisia tabaci (Hom.: Aleyrodidae) in protected sweet pepper crops in Southern Spain. Integrated Control in Protected Crops, Mediterranean Climate IOBC/wprs Bulletin 29(4): 73-78.

Canlas, L.J., H. Amano, N. Ochiai and M. Takeda. 2006. Biology and predation of the Japanese strain of Neoseiulus californicus (McGregor) (Acari: Phytoseiidae). Systematic and Applied Acarology 11: 141-157.

Horowitz, A.R., K. Gorman, G. Ross and I. Denholm. 2003. Inheritance of pyriproxyfen resistance in the whitefly, Bemisia tabaci (Q biotype). Arch. Insect Biochem. Physiol. 54: 177-186.

Jones, D. 2003. Plant viruses transmitted by whiteflies. Eur. J. Plant Pathol. 109: 197-221.

Lee, M., S. Kang, S. Lee, H.-S. Lee, J.-Y. Choi, G.-S. Lee, W.-Y. Kim, S.-W. Lee, S.-G. Kim and K.-B. Uhm. 2005. Occurrence of the B- and Q-biotypes of Bemisia tabaci in Korea. Korean J. Appl. Entomol. 44(3): 169-175. in Korean with English abstract.

McMurtry, J.A. and B.A. Croft. 1997. Life-style of phytoseiid mites and their role in biological control. Ann. Rev. Entomol. 42: 291-321.

Messelink, G.J., S.E.F. van Steenpaal and P.M.J. Ramakers. 2006. Evaluation of phytoseiid predators for control of western flower thrips on greenhouse cucumber. Biocontrol 51: 753-768.

Nombela, G., F. Beitia and M. Muñiz. 2001. A differential interaction study of Bemisia tabaci Q-biotype on commercial tomato varieties with and without the Mi resistance gene, and comparative host responses with the B-biotype. Entomol. Exp. Appl. 98: 339-344.

Nomikou, M., A. Janssen, R. Schraag and M.W. Sabelis. 2001. Phytoseiid predators as potential biological control agents for Bemisia tabaci. Experimental and Applied Acarology 25: 271291.

Nomikou, M., A. Janssen, R. Schraag and M.W. Sabelis, 2002. Phytoseiid predators suppress populations of Bemisia tabaci on cucumber plants with alternative food. Exp. Appl. Acarol. 27: 57-68.

Nomikou, M., A. Janssen and M.W. Sabelis. 2003. Phytoseiid predator of whitefly feeds on plant tissue. Experimental and Applied Acarology 31: 27-36.

Nomikou, M. 2003. Combating whiteflies: Predatory mites as a novel weapon. Ph. D. Thesis, Section Population Biology, University of Amsterdam. 156pp.

Swirski, E., S. Amitai and N. Dorzia. 1970. Laboratory studies on the feeding habits, postembryonic survival and oviposition of the predaceous mites Amblyseius chilensis Dosse and Amblyseius hibisci Chant (Acarina: Phytoseiidae) on various kinds of food substances. Entomophaga 15: 93-106.

(Received for publication June 20 2008;

revised June 23 2008; accepted November 25 2008) 